\begin{tabular}{|c|c|c|c|}
\hline \multirow{3}{*}{$\begin{array}{r}\text { Case Reports in } \\
\text { Gastroenterology }\end{array}$} & Case Rep Gastroenterol 2 & & \multirow[b]{2}{*}{$\begin{array}{l}\text { Karger } \\
\text { Opengccess }\end{array}$} \\
\hline & $\begin{array}{l}\text { DOI: 10.1159/000464277 } \\
\text { Publisned onlıne: April I0, } 2017\end{array}$ & $\begin{array}{l}\text { (C) } 2017 \text { The Author(s) } \\
\text { Published by S. Karger AG, Basel } \\
\text { www.karger.com/crg }\end{array}$ & \\
\hline & $\begin{array}{l}\text { This article is licensed under } \\
\text { International License (CC BY-N } \\
\text { Usage and distribution for comm }\end{array}$ & $\begin{array}{l}\text { nons Attribution-NonCommercial } \\
\text { ger.com/Services/OpenAccessLicens } \\
\text { uires written permission. }\end{array}$ & \\
\hline
\end{tabular}

\title{
A Foreign Body (Toothbrush) in the Esophagus of a Patient with Hiatal Hernia
}

\author{
Marisa Klancnik ${ }^{a} \quad$ Maja Grgec ${ }^{a} \quad$ Nikola Perković ${ }^{b} \quad$ Petar Ivaniševića $^{a}$ \\ Nikola Kolja Poljak ${ }^{\mathrm{a}}$ \\ ${ }^{a}$ Clinical Department for Ear Nose and Throat, Split University Hospital Center, \\ Split, Croatia; ${ }^{b}$ Clinical Department for Internal Medicine, Division of Gastroenterology, \\ Split University Hospital Center, Split, Croatia
}

\section{Keywords}

Toothbrush · Esophageal foreign body · Hiatal hernia · Endoscopy

\begin{abstract}
Toothbrush ingestion is rare and most commonly seen in patients with psychiatric comorbidities and in young women with a medical history of eating disorders who try to induce emesis. Long ingested objects, such as a toothbrush, cannot pass the gastrointestinal tract spontaneously and require endoscopic removal or even a surgical approach in cases of unsuccessful endoscopic removal or complication development. We present a case of a 71-yearold male with hiatal hernia without psychiatric or neurological comorbidity who accidentally ingested a toothbrush during oral hygiene routine. After X-ray confirmation, the toothbrush was removed endoscopically.

(C) 2017 The Author(s)

Published by S. Karger AG, Basel
\end{abstract}

\section{Introduction}

Foreign body ingestion is commonly seen in clinical practice and treated by otolaryngology and gastroenterology specialists. Ingestion of true foreign bodies (i.e., nonfood objects) occurs more commonly in children than in adults [1]. In adults, foreign body ingestion appears usually in patients with intellectual impairment, psychiatric illness, alcohol intoxica- 


\section{Case Reports in Gastroenterology}

Case Rep Gastroenterol 2017;11:184-189 DOI: 10.1159/000464277 c 2017 The Author(s). Published by S. Karger AG, Basel www.karger.com/crg

Klancnik et al.: A Foreign Body (Toothbrush) in the Esophagus of a Patient with Hiatal Hernia

tion, or in the elderly population and in prisoners seeking secondary gain [2-5]. Dentures, coins, and buttons are commonly swallowed objects [6]. Toothbrush as an esophageal foreign body is more common in young females with eating disorders such as anorexia nervosa and bulimia in the age group of 15-23 [7-10]. Fortunately, the vast majority of ingested objects pass the gastrointestinal tract spontaneously and only about $20 \%$ need intervention for removal, either by endoscope or surgical removal. Toothbrush is a rare esophageal foreign body, and because of its shape and size, it cannot pass the gastrointestinal tract spontaneously. Foreign bodies longer than 5-6 cm, such as a toothbrush, cannot pass the duodenal Cloop due to its fixed retroperitoneal position. Structural and functional esophageal abnormalities increase the risk of foreign body impaction in the esophagus [1].

\section{Case Presentation}

A-71-year-old Caucasian male presented to the ENT emergency department $1 \mathrm{~h}$ after accidentally swallowing a toothbrush during his oral hygiene routine. He denied that he had tried to induce emesis. The patient did not have any previous medical history of psychiatric or neurologic illness. There was no history of eating disorder, and alcohol or drug intoxication was not suspected. The patient mentioned a stomach operation performed 4 months ago in another clinic. Based on his medical history, the above-mentioned surgical procedure was most likely due to hiatal hernia, but there was no available medical documentation to confirm it. On presentation, the patient reported mild discomfort in the neck and chest region. Vital signs were within normal limits: blood pressure, 140/90 mm Hg; breathing, 15 breaths/min; pulse, 80 beats/ min; oxygen saturation, 98\%. The patient was afebrile $\left(36.5^{\circ} \mathrm{C}\right)$. On lung auscultation, there were normal low-pitched vesicular breath sounds over most of the peripheral lung fields. On oropharyngeal examination of the buccal mucosa, the hard and soft palate as well as pharyngeal mucosa appeared without signs of acute injury caused by a foreign body (e.g., laceration). Indirect laryngoscopy examination showed moderate pooling of saliva in both pyriform fossae. The interarytenoid mucosa appeared slightly edematous and hyperemic. Laboratory results revealed inflammatory parameters within the normal range (white blood cell count, $6 \times 10^{9} / \mathrm{L}$; CRP $2 \mathrm{mg} / \mathrm{L}$ ). Plain X-ray of the neck, thorax, and abdomen was performed. A plain X-ray study confirmed the presence of a foreign body at the sternoclavicular joint level (Fig. 1, Fig. 2). On profile view, the foreign body was confirmed to be in the esophagus, behind the trachea. Paracardiac opacity with air fluid level was also observed due to hiatal hernia. A gastroenterology specialist was consulted, and after patient informed consent, upper gastrointestinal endoscopy was performed. After visualization using a polypectomy snare, the toothbrush was successfully removed. The procedure lasted $10 \mathrm{~min}$ and was uneventful. The length of the extracted toothbrush was $20 \mathrm{~cm}$. Six hours later, the repeated endoscopy procedure did not show evidence of mucosal lesions of the esophagus. After a 12-h observation, the patient was discharged home.

\section{Discussion}

Approximately $80-90 \%$ of the ingested foreign bodies pass the gastrointestinal tract spontaneously, while $10-20 \%$ of the cases require endoscopic removal and $<1 \%$ require surgery for extraction or complication treatment $[3,11,12]$. Most often, impaction and perforation occur at areas of physiological narrowing or angulation, which include the upper 


\section{Case Reports in Gastroenterology}

Case Rep Gastroenterol 2017;11:184-189 DOI: 10.1159/000464277 c 2017 The Author(s). Published by S. Karger AG, Basel www.karger.com/crg

Klancnik et al.: A Foreign Body (Toothbrush) in the Esophagus of a Patient with Hiatal Hernia

esophageal sphincter, pylorus, ileocecal valve, and duodenal sweep. Objects greater than 5-6 $\mathrm{cm}$ cannot pass the duodenal sweep [1]. With foreign bodies impacted in the esophagus for more than $24 \mathrm{~h}$, the risk of perforation increases 14.1 times [13]. The risk of complication for ingested sharp-pointed objects is up to 35\% [11]. The European Society of Gastrointestinal Endoscopy (ESGE) Clinical Guideline classified swallowed foreign bodies into different types: blunt objects (coins, buttons, magnets, etc.), sharp-pointed objects (needles, toothpicks, bones, partial dentures, razor blades, etc.), long objects (soft: strings, cords; hard objects: toothbrushes, pens, pencils), food bolus, and others. There is strong recommendation to perform plain radiography, if ingestion of a radiopaque object is suspected or the type of object is unknown. CT is recommended in all patients with suspected perforation or other complications that may require surgery. Barium swallow should not be performed due to the risk of aspiration and worsening of the endoscopic visualization [1]. It is important to note that perforation can be seen on X-ray, but the imaging data can be similar to hiatal hernia and therefore lead to misdiagnosis of a coexisting hiatal hernia as esophageal perforation $[14,15]$. Due to this fact, appropriate medical history should be taken. Regarding the endoscopic measures, ESGE recommends emergent (within $6 \mathrm{~h}$ ) therapeutic esophagogastroduodenoscopy for foreign bodies inducing complete esophageal obstruction, sharp pointedobjects, or batteries in the esophagus and urgent (within $24 \mathrm{~h}$ ) therapeutic esophagogastroduodenoscopy for sharp-pointed objects, magnets, and large/long objects in the stomach.

In the case of ingested long foreign bodies such as a toothbrush, early endoscopy and removal is necessary.

\section{Conclusion}

An ingested toothbrush cannot pass the gastrointestinal tract spontaneously and necessitates medical intervention. The presence of an ingested toothbrush can be determined by plain X-ray, which should be followed by immediate endoscopic removal. A surgical approach is recommended in cases in which endoscopic removal fails or if complications develop.

\section{Statement of Ethics}

Informed consent from the patient was obtained for publishing the case report.

\section{Disclosure Statement}

The authors have no conflicts of interest to declare.

\section{References}

1 Birk M, Bauerfeind P, Deprez P, Häfner M, Hartmann D, Hassan C, et al: Removal of foreign bodies in the upper gastrointestinal tract in adults: European society of gastrointestinal Endoscopy (ESGE) clinical guideline. Endoscopy 2016;48:489-496.

-2 Dray X, Cattan P: Foreign bodies and caustic lesions. Best Pract Res Clin Gastroenterol 2013;27:679689. 


\section{Gastroenterology} \begin{tabular}{l|l}
\hline DOI: $10.1159 / 000464277$ & (C) 2017 The Author(s). Published by S. Karger AG, Basel
\end{tabular} www.karger.com/crg

Klancnik et al.: A Foreign Body (Toothbrush) in the Esophagus of a Patient with Hiatal Hernia

3 Pfau PR: Removal and management of esophageal foreign bodies. Tech Gastrointest Endosc

2014;16:32-39.

4 Lu XL, Cao HL, Qian KD: Endoscopic removal of an accidentally swallowed toothbrush. Intern Med 2008;47:1797-1798.

5 Dalal PP, Otey AJ, McGonagle EA, Whitmill ML, Levine EJ, McKimmie RL, et al: Intentional foreign object ingestions: need for endoscopy and surgery. J Surg Res 2013;184:145-149.

-6 Yao CC, Wu IT, Lu LS, Lin SC, Liang CM, Kuo YH, et al: Endoscopic management of foreign bodies in the upper gastrointestinal tract of adults. Biomed Res Int 2015;2015:658602.

7 Palta R, Sahota A, Bemarki A, Salama P, Simpson N, Laine L: Foreign-body ingestion: Characteristics and outcomes in a lower socioeconomic population with predominantly intentional ingestion. Gastrointest Endosc 2009;69:426-433.

-8 Kim IH, Kim HC, Koh KH, Kim SH, Lee SO: Journey of a swallowed toothbrush to the colon. Korean J Intern Med 2007;22:106-108.

Kirk AD: Toothbrush swallowing. Arch Surg 1988;123:382.

10 Riddlesberger MM, Cohen HL, Glick PL: The swallowed toothbrush: a radiographic clue of bulimia. Pediatr Radiol 1991;21:262-264.

11 Smith MT, Wong RKH: Foreign bodies. Gastrointest Endosc Clin N Am 2007;17:361-382.

-12 Webb WA: Management of foreign bodies of the upper gastrointestinal tract: update. Gastrointest Endosc 1995;41:39-51.

-13 Loh K: Complications of foreign bodies in the esophagus. Otolaryngol Head Neck Surg 2000;123:613616.

$\$ 14$ Lu YP: False esophageal hiatus hernia caused by a foreign body: a fatal event. World J Gastroenterol 2014;20:14510.

15 Chen CY, Lee SC, Chen JC: Denture mis-swallowing in the sliding esophageal hiatal hernia mimics esophageal perforation. J Formos Med Assoc 2008;107:663-666. 


\section{Case Reports in Gastroenterology}

\begin{tabular}{l|l}
\hline Case Rep Gastroenterol 2017;11:184-189 \\
\hline DOI: 10.1159/000464277 & $\begin{array}{l}\text { (c) 2017 The Author(s). Published by S. Karger AG, Basel } \\
\text { www.karger.com/crg }\end{array}$ \\
\hline
\end{tabular}

Klancnik et al.: A Foreign Body (Toothbrush) in the Esophagus of a Patient with Hiatal Hernia

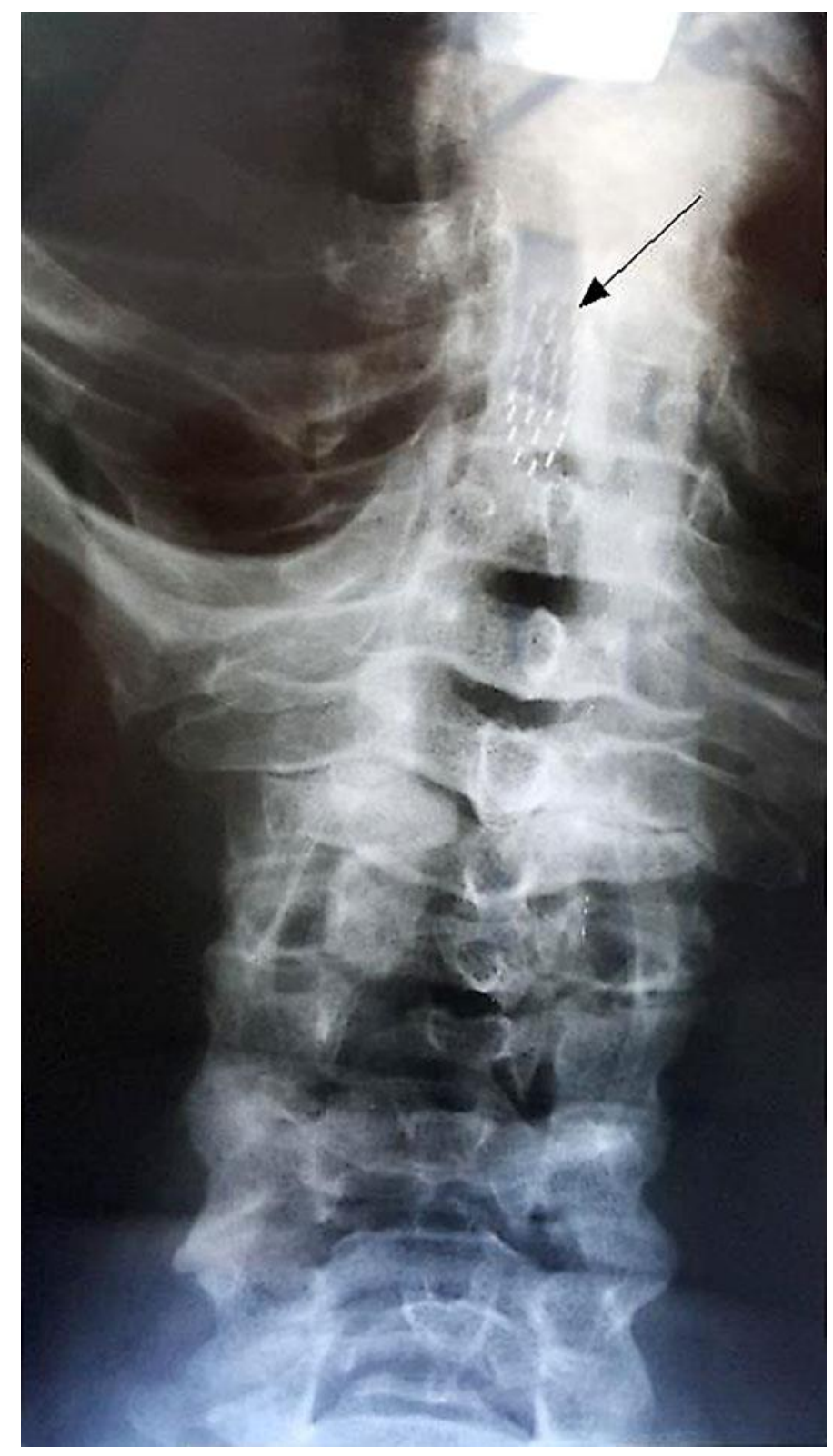

Fig. 1. Radiopaque part of the toothbrush is seen at the sternoclavicular joint level on plain X-ray (arrow). 


\section{Case Reports in Gastroenterology}

\begin{tabular}{l|l}
\hline Case Rep Gastroenterol 2017;11:184-189 \\
\hline DOI: 10.1159/000464277 & $\begin{array}{l}\text { @ 2017 The Author(s). Published by S. Karger AG, Basel } \\
\text { www.karger.com/crg }\end{array}$ \\
\hline
\end{tabular}

Klancnik et al.: A Foreign Body (Toothbrush) in the Esophagus of a Patient with Hiatal Hernia

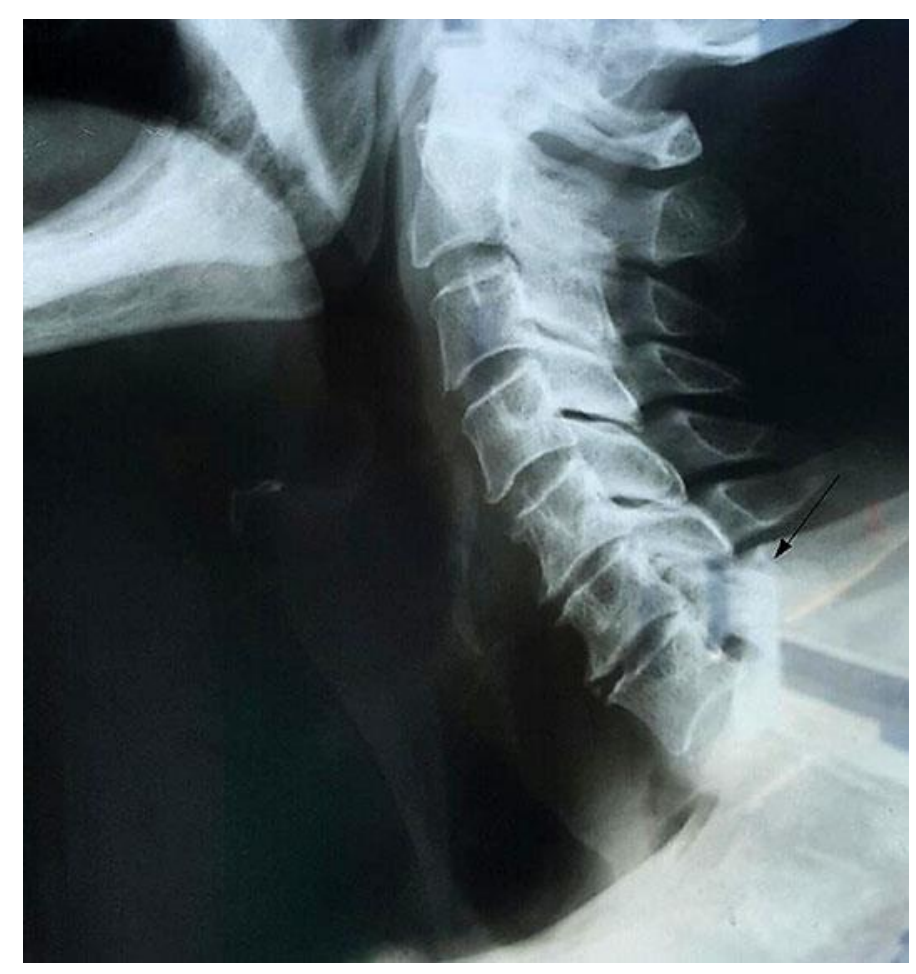

Fig. 2. Radiopaque part of the toothbrush is seen at the sternoclavicular joint level on plain X-ray (arrow). 